\title{
Physiological parameter of Maize as Influenced by INM Modules under Maize-Chickpea Sequence in a Vertisol of Central India
}

\author{
C. K. Dotaniya ${ }^{1 *}$, B.L. Lakaria ${ }^{2}$, Yogesh Sharma ${ }^{1}$, A.K. Biswas ${ }^{2}$, \\ B.P. Meena ${ }^{2}$, M.L. Reager ${ }^{3}$, S.R. Yadav $^{1}$ and S.B. Aher ${ }^{4}$
}

${ }^{1}$ Department of Soil Science \& Agricultural Chemistry, SKRAU, Bikaner- 334 006, India

${ }^{2}$ ICAR-Indian Institute of Soil Science, Nabibagh, Bhopal- 462 038, India

${ }^{3}$ Krishi Vigyan Kendra, SKRAU, Bikaner- 334 006, India

${ }^{4}$ ICMR-National Institute for Research in Environmental Health, Bhopal- 462 030, India

*Corresponding author

Keywords

Maize, Crop growth, Seed index, INM modules,

Vertisol

\section{Article Info}

Accepted:

18 August 2020

Available Online:

10 September 2020

\section{A B S T R A C T}

A present investigation was conducted at Research Farm, ICAR-Indian Institute of Soil Science, Bhopal during 2017-18 and 2018-19 to study the performance of maize crop under various nutrient management modules in a Vertisol. The field experiment was laid out in RBD consisting of 12 different integrated nutrient management (INM) modules in three replications. The maize (cv. Pro Agro - 4212) and chickpea (cv. JG-315) was grown in kharif and rabi seasons during 2017 and 2018 with an identified set of treatments. The performance of crops under these treatments was assessed in terms of plant height and seed index. Similarly, the soil physico-chemical properties were also assessed at crop harvest. Finally, the correlation among various studied parameters was worked out. The results revealed that the INM modules positively influenced the performance and productivity of maize crop as compared to the sole inorganic fertilizer application. Besides the superior crop performance, the integrated nutrient management modules significantly $(\mathrm{p}=0.05)$ enhanced and improved soil health in terms of soil physico-chemical properties. Among the various modules, (1) application of 75\% STCR dose + FYM @ $5 \mathrm{t} \mathrm{ha}{ }^{-1}$ to maize, (2) application of FYM @ 20t ha ${ }^{-1}$ to maize increased the crop growth and seed index in maize, improved soil health and reflected as a viable technique in improving soil nutrient availability on a sustainable basis. 


\section{Introduction}

Maize (Zea mays L.) is one of the most important crops cultivated throughout the worldas food, feed and industrial raw material which ranked third largest cereals following rice and wheat, respectively (FAO, 2009; Hasan et al., 2018). Long-term fertilizer experiments are played an important role in understanding the complex interaction involving plants, soil and management practices and their effects on crop performance and soil properties (Meena et al., 2019). It also provides opportunities to investigate the crop growth and yield trend, crop productivity, soil health parameters and evaluate the factors are responsible for the sustainable crop production and soil health management (Singh and Wanjari, 2012). Long- term experiments have indicated that imbalanced use of nutrients through chemical fertilizers without addition of organic manures accelerated the degradation of soil quality and declined crop productivity in intensive cropping system (Sharma et al., 2017). India is facing a difficult situation where the human population to feed would continue to increase at an alarming rate while the available cultivated land area is shrinking due to fast urbanization and industrialization. Hence, the adoption of intensive cropping is unavoidable for higher food grain production. Secondly, most of farmers are preferred to apply only nitrogenous fertilizer to crops because of its immediate visual effects either on plants or higher cost of phosphatic and potassic fertilizers, resulting in an imbalance of nutrient consumption leading to exhaustion of nutrients from the soil. Sustenance of high crop yield levels is possible through the judicious use of manures and fertilizers. Inclusion of cereal-legume crop rotation with the addition of organic manures along with optimum NPK application to soil system is essential for sustaining crop productivity and maintaining the soil health (Sharma and
Behera, 2009). Maize-chickpea rotation is an important cropping sequence of India. Maize is one of the important cereal crops in the world's agricultural economy both as food for humans and as feed for animals. Of this cropping sequence, maize is considered as the most exhaustive crop after sugarcane and requires both micro and macro-nutrients throughout its growing period to obtain high growth and yield potentials. Long-term sustainability concerns are growing in agriculture owing to over and under the application of fertilizers and poor management of available resources, which are resulting in soil health deterioration and declining crop productivity. Integrated use of organic and inorganic sources of nutrients is the most logical concept for managing and sustaining soil health and crop productivity (Dotaniya et al., 2019). Integrated nutrient management is one of the most important components for enhancing crop production and sustaining soil fertility (Lakaria et al., 2012). Maize is one of the most versatile emerging crops having wider adaptability under varied agro-climatic conditions. It is one of the important cereal crops in the world's agricultural economy both as food for human and as feed for animals. Globally, it is known as queen of cereals due to higher genetic yield potential among cereals. In India, maize is the third most important food crops after rice and wheat. It occupied an area of $9.63 \mathrm{~m}$ ha with production of $25.90 \mathrm{mt}$ and yield of $2689 \mathrm{~kg} \mathrm{ha}^{-1}$ in 2016-17 while in 2017-18 the area and production of maize was recorded $9.47 \mathrm{~m} \mathrm{ha}$, and production $28.72 \mathrm{mt}$ and 3032 yield $\mathrm{kg} \mathrm{ha}^{-1}$ respectively. In India, Madhya Pradesh stands at first position in terms of area and third position in production of maize after Karnataka (Agricultural Statistics, 2018). Keeping in view the above the present study was undertaken to study the performance of maize under various INM modules. Hypothesis elucidated the crop growth performance of maize was carried out 
to know the effect of organic and inorganic fertilizer on growth parameters of maize.

\section{Materials and Methods}

A field experiment was conducted at the research farm of the ICAR-Indian Institute of Soil Science, Bhopal. The soil of the experimental site is classified as Vertisol (Typic Haplusterts) with smectite as the dominant clay mineral. Vertisols are churning heavy clay soils with a high proportion of swelling clays. These soils form deep wide cracks during the summer season. The soil of the experimental site was clayey in texture with 25.2, 18.0 and 56.8 per cent of sand, silt and clay, respectively. The soil was medium in soil organic carbon $(0.53 \%)$, low in available $\mathrm{N}$ (68.8 $\left.\mathrm{mg} \mathrm{kg}^{-1}\right)$, medium in available $\mathrm{P}$ (12.8 $\left.\mathrm{mg} \mathrm{kg}^{-1}\right)$ and high in available $\mathrm{K}$ (237 $\left.\mathrm{mg} \mathrm{kg}^{-1}\right)$. The soil was normal in reaction $(\mathrm{pH} \mathrm{7.76)}$ and electrical conductivity (EC) was $0.48 \mathrm{dS} \mathrm{m} \mathrm{m}^{-1}$. The performance of maize was evaluated by monitoring crop growth parameters viz., plant height, seed index (100 seed weight). The experiment comprised of 12 treatments (Table 1) laid out in a Randomized Blocks Design (RBD) with 3 replications. All the measurements having the mean value of three separate replicates. Data were subjected to an analysis of variance. The mean values were grouped for comparisons and the least significant differences among them were calculated at $P<0.05$ confidence level using ANNOVA statistics as outlined by (Gomez and Gomez, 1983).

\section{Results and Discussion}

\section{Results}

\section{Plant height at 45 DAS}

Plant height was found significantly $(\mathrm{p}=0.05)$ different at 45 DAS ranged $46.7-104.0 \mathrm{~cm}$,
49.7 - $118.3 \mathrm{~cm}$ and $48.2-111.2 \mathrm{~cm}$ during 2017, 2018 and pooled of two years, respectively (Table 2 and Fig. 1). Similarly, average plant height of maize at 45 DAS across the treatments was $86.5 \mathrm{~cm}, 93.8 \mathrm{~cm}$ and $90.1 \mathrm{~cm}$ during 2017, 2018 and pooled of two years, respectively. The pooled data of two years with respect to plant height revealed that application of FYM@20t ha ${ }^{-1}$ in kharif and $5 \mathrm{t} \mathrm{ha}^{-1}$ in rabi season $\left(\mathrm{T}_{11}\right)$ and STCR recommended dose of fertilizers $\left(\mathrm{T}_{3}\right)$ were significantly superior over rest of the other treatments. These were found statistically at par with each other. Similarly, the treatment receiving general recommended dose $\left(\mathrm{T}_{2}\right), 75 \%$ STCR dose + FYM @ 5t ha ${ }^{-1}$ $\left(\mathrm{T}_{5}\right), 75 \%$ STCR dose + UC@ 5t ha ${ }^{-1}\left(\mathrm{~T}_{7}\right)$, FYM@5t ha ${ }^{-1}+$ Glyricidia@ $@ 2 \mathrm{ha}^{-1}+$ incorporation of maize residues $\left(\mathrm{T}_{10}\right)$ and 75\% STCR dose + FYM @ 20t ha ${ }^{-1}$ once in 4 year $\left(\mathrm{T}_{12}\right)$ found statistically at par with each other. The treatments $\mathrm{T}_{9}\left(\mathrm{PM} @ 1 \mathrm{t} \mathrm{ha}^{-1}+\right.$ Glyricidia@2t ha ${ }^{-1}+$ incorporation of maize residues), $\mathrm{T}_{6}$ (75\% STCR dose + PM @ 1 $\left.\mathrm{t} \mathrm{ha}^{-1}\right)$ and $\mathrm{T}_{8} \quad(75 \%$ STCR dose + incorporation of maize residues) were also found statistically at par with respect to plant height of maize recorded at 45 DAS.

\section{Plant height at 60 DAS}

The maize plant height recorded at 60 DAS ranged $98.2-182.3 \mathrm{~cm}, 96.4-186.5 \mathrm{~cm}$ and 97.3 - $184.4 \mathrm{~cm}$ during 2017, 2018 and pooled, respectively (Table 2 and Fig. 1). Similarly, average plant height of maize at 60 DAS across the treatments was found 147.0 $\mathrm{cm}, 150.0 \mathrm{~cm}$ and $148.5 \mathrm{~cm}$ during 2017 , 2018and pooled data of two years, respectively. The pooled data of two years with respect to plant height of maize recorded at 60 DAS revealed that the treatment receiving FYM@ 20t $\mathrm{ha}^{-1}\left(\mathrm{~T}_{11}\right)$ and the treatment receiving STCR recommended dose of fertilizers $\left(\mathrm{T}_{3}\right)$ found superior over rest other treatments, whereas found statistically 
at par with each other. Similarly, treatments receiving GRD $\left(\mathrm{T}_{2}\right), 75 \%$ STCR dose + PM @ 1t ha- $\left.{ }^{-1} \mathrm{~T}_{6}\right), 75 \%$ STCR dose + UC@ $0 \mathrm{t} \mathrm{ha}^{-}$ ${ }^{1}\left(\mathrm{~T}_{7}\right)$, FYM @ 5t ha ${ }^{-1}+$ Glyricidia @ $2 \mathrm{t} \mathrm{ha}^{-1}+$ incorporation of maize residues $\left(\mathrm{T}_{10}\right)$ and 75\% STCR dose + FYM @ 20t ha ${ }^{-1}$ once in 4 year $\left(\mathrm{T}_{12}\right)$ found statistically at par. The treatment involving the sole application of $75 \%$ STCR dose $\left(\mathrm{T}_{4}\right)$ showed poorest performance among all the treatments after $\mathrm{T}_{1}$ (control). The treatments $\mathrm{T}_{5}$ (75\% STCR dose + FYM @ 5t ha $\left.{ }^{-1}\right), \mathrm{T}_{6}(75 \%$ STCR dose + PM @ 1t ha $\left.^{-1}\right), \quad \mathrm{T}_{8} \quad(75 \% \quad$ STCR dose + incorporation of maize residues) and $\mathrm{T}_{9}(\mathrm{PM}$ @ 1t $\mathrm{ha}^{-1}+$ Glyricidia@ 2t $\mathrm{ha}^{-1}+$ incorporation of maize residues) were also found statistically at par with respect to plant height of maize recorded at 60 DAS.

\section{Plant height at 90 DAS}

The data revealed that the plant height of maize recorded at 90 DAS ranged 130.3 $208.3 \mathrm{~cm}, 137.5-220.2 \mathrm{~cm}$ and $133.9-214.3$ $\mathrm{cm}$ during 2017, 2018 and pooled data of two years, respectively presented (Table 2 and Fig. 1). Similarly, the average plant height of maize at 90 DAS across the treatments was found $177.7 \mathrm{~cm}, 189.0 \mathrm{~cm}$ and $183.3 \mathrm{~cm}$ during 2017, 2018 and pooled of two years, respectively. The pooled data of two years with respect to plant height of maize at 90 DAS revealed that the treatment receiving FYM@20t ha ${ }^{-1}\left(T_{11}\right)$ found superior over rest other treatments except treatment $\mathrm{T}_{3}$ (STCR recommended dose of fertilizers). Similarly, the treatment receiving general recommended dose $\left(\mathrm{T}_{2}\right), \mathrm{T}_{3}, 75 \%$ STCR dose + UC@ $9 \mathrm{t} \mathrm{ha}^{-1}$ $\left(\mathrm{T}_{7}\right), \mathrm{FYM} @ 5 \mathrm{tha}^{-1}+$ Glyricidia@ 2t ha ${ }^{-1}+$ incorporation of maize residues $\left(\mathrm{T}_{10}\right)$ and $75 \%$ STCR dose + FYM @ 20t ha ${ }^{-1}$ once in 4 year $\left(\mathrm{T}_{12}\right)$ were found statistically at par. The unfertilized control $\left(\mathrm{T}_{1}\right)$ recorded lowest plant height among all the treatments under study. The treatments $\mathrm{T}_{4}\left(75 \%\right.$ STCR dose), $\mathrm{T}_{5}(75 \%$ STCR dose + FYM @ 5t ha $\left.{ }^{-1}\right), \mathrm{T}_{6}(75 \%$
STCR dose + PM @ 1t ha $\left.{ }^{-1}\right), \mathrm{T}_{8}(75 \%$ STCR dose + incorporation of maize residues) and $\mathrm{T}_{9}$ (PM@1t ha ${ }^{-1}+$ Glyricidia@2t ha $\mathrm{ha}^{-1}+$ incorporation of maize residues) were also found statistically $(\mathrm{p}=0.05)$ at par with respect to plant height of maize recorded at $90 \mathrm{DAS}$.

\section{Seed index}

Seed index (100 seed weight) of maize recorded during 2017, 2018 and pooled of two years is presented in Table 2 and Fig. 2. The seed index of maize ranged between 20.4 - $34.9 \mathrm{~g}, 19.0$ - $32.4 \mathrm{~g}$ and 19.7 - $33.7 \mathrm{~g}$ during 2017, 2018 and for pooled data of two years, respectively. Similarly, the average seed index of maize across the treatments was found $25.9 \mathrm{~g}, 23.1 \mathrm{~g}$ and $24.5 \mathrm{~g}$ during 2017 , 2018 and pooled of two years, respectively. The pooled data of two years with respect to seed index revealed that the treatment receiving 75\% STCR dose + FYM @ $5 \mathrm{t} \mathrm{ha}^{-1}$ $\left(\mathrm{T}_{5}\right)$ recorded highest seed index $(33.7 \mathrm{~g})$ followed by the treatment $\mathrm{T}_{3}$ (STCR recommended dose of fertilizers; $28.6 \mathrm{~g}$ ). The treatments other than $\mathrm{T}_{3}$ and $\mathrm{T}_{11}$ didn't show any significant difference with respect to the seed index of the maize. Even, control and treatments $\mathrm{T}_{4}\left(75 \%\right.$ STCR dose), $\mathrm{T}_{6}(75 \%$ STCR dose + PM @ 1t ha $\left.{ }^{-1}\right), \mathrm{T}_{8}$ (75\% STCR dose + incorporation of maize residues) and $\mathrm{T}_{9}$ (PM@1t ha ${ }^{-1}+$ Glyricidia@2t ha ${ }^{-1}+$ incorporation of maize residues) were also found statistically at par with each other with respect to seed index of maize.

The performance of the maize and chickpea crop with respect to the growth and yield attributes, grain yield and biomass has been recorded during the experimental period. The growth and yield attributes measured were plant height at various growth stages and seed index. Plant height of maize was recorded at 45 DAS, 60 DAS and 90 DAS respectively during the study years viz., 2017-18 and 2018-19. The results revealed that the plant 
height of maize recorded at periodic interval during the study period found significantly higher under the treatment receiving FYM @
$20 \mathrm{t} \mathrm{ha}^{-1}\left(\mathrm{~T}_{11}\right)$ and the treatment receiving STCR recommended dose of fertilizers $\left(\mathrm{T}_{3}\right)$ as compared to the other treatments.

Table.1 Treatment applied in maize-chickpea cropping sequence.

\begin{tabular}{|c|c|c|}
\hline Treatment & Maize & Chickpea \\
\hline$T_{1}$ Control & No Fertilizer/ Manure & No Fertilizer/ Manure \\
\hline T. $_{2 .}$ GRD & $120-60-30$ & $20-60-20$ \\
\hline $\mathbf{T}_{3 .}$ STCR & STCR dose for $5 \mathrm{t} \mathrm{ha}^{-1}$ maize $(135-55-50)$ & $\begin{array}{l}\text { STCR dose for } \\
1.5 \mathrm{tha}^{-1}(0-0-0)\end{array}$ \\
\hline $\mathbf{T}_{4}$ & $75 \% \mathrm{NPK}$ of $\mathrm{T}_{3}$ & $100 \%$ P only \\
\hline $\mathbf{T}_{5}$ & $75 \%$ NPK of $T_{3}+5 \mathrm{tha}^{-1} \mathrm{FYM}$ & $100 \%$ P only \\
\hline $\mathbf{T}_{6}$ & $75 \% \mathrm{NPK}$ of $\mathrm{T}_{3}+1 \mathrm{tha}^{-1} \mathrm{PM}$ & $100 \%$ P only \\
\hline $\mathbf{T}_{7}$ & $75 \% \mathrm{NPK}$ of $\mathrm{T}_{3}+5 \mathrm{tha}^{-1} \mathrm{UC}$ & $100 \%$ P only \\
\hline $\mathbf{T}_{8}$ & $75 \%$ NPK of $\mathrm{T}_{3}+\mathrm{MR}$ mulch incorporated & $100 \%$ P only + MR mulch \\
\hline $\mathbf{T}_{9}$ & $\begin{array}{l}1 \mathrm{t} \mathrm{ha}^{-1} \mathrm{PM}+\text { Gly } 2 \mathrm{t} \mathrm{ha}^{-1}+\mathrm{MR} \text { mulch } \\
\text { incorporated }\end{array}$ & $100 \%$ P only + MR mulch \\
\hline $\mathbf{T}_{10}$ & $\begin{array}{l}5 \mathrm{t} \mathrm{ha}^{-1} \mathrm{FYM}+\text { Gly } 2 \mathrm{t} \mathrm{ha}^{-1}+\mathrm{MR} \text { mulch } \\
\text { incorporated }\end{array}$ & $100 \%$ P only + MR mulch \\
\hline $\mathbf{T}_{11}$ & $20 \mathrm{t} \mathrm{ha}^{-1} \mathrm{FYM}$ (every season) & $5 \mathrm{t} \mathrm{ha}^{-1}$ FYM (Every Season) \\
\hline$T_{12}$ & $\begin{array}{l}75 \% \mathrm{NPK} \text { of } \mathrm{T}_{3}+20 \mathrm{tha}^{-1} \mathrm{FYM} \text { (once in } 4 \\
\text { years) }\end{array}$ & $100 \%$ P only \\
\hline
\end{tabular}

GRD - General recommended dose $\left(\mathrm{kg} \mathrm{ha}^{-1)}\right.$, STCR - Soil test crop response dose, MR - Maize residues, FYM Farm yard manure, PM - Poultry manure, UC - Urban compost, Gly - Glyricidia

Table.2 Crop growth performance by maize under different INM modules

\begin{tabular}{|c|c|c|c|c|c|c|c|c|c|c|c|c|}
\hline \multirow[t]{3}{*}{ Treatments } & \multicolumn{9}{|c|}{ Plant height (cm) } & \multirow{2}{*}{\multicolumn{3}{|c|}{ Seed Index (g) }} \\
\hline & \multicolumn{3}{|c|}{45 DAS } & \multicolumn{3}{|c|}{60 DAS } & \multicolumn{3}{|c|}{90 DAS } & & & \\
\hline & 2017 & 2018 & Pooled & 2017 & 2018 & Pooled & 2017 & 2018 & Pooled & 2017 & 2018 & Pooled \\
\hline $\mathbf{T}_{1}$ & 46.7 & 49.7 & 48.2 & 98.2 & 96.4 & 97.3 & 130.3 & 137.5 & 133.9 & 20.4 & 19.0 & 19.7 \\
\hline $\mathbf{T}_{2}$ & 93.7 & 97.0 & 95.3 & 160.7 & 160.2 & 160.4 & 183.0 & 196.4 & 189.7 & 25.5 & 23.4 & 24.5 \\
\hline $\mathbf{T}_{3}$ & 100.0 & 112.7 & 106.3 & 182.0 & 186.5 & 184.3 & 201.0 & 209.9 & 205.5 & 29.7 & 27.4 & 28.6 \\
\hline $\mathbf{T}_{4}$ & 78.0 & 82.3 & 80.2 & 116.7 & 118.2 & 117.4 & 168.0 & 169.5 & 168.7 & 22.8 & 20.7 & 21.8 \\
\hline $\mathbf{T}_{5}$ & 90.0 & 95.0 & 92.5 & 128.3 & 136.5 & 132.4 & 175.7 & 194.9 & 185.3 & 34.9 & 32.4 & 33.7 \\
\hline $\mathbf{T}_{6}$ & 80.7 & 94.3 & 87.5 & 149.0 & 153.2 & 151.1 & 174.7 & 187.0 & 180.8 & 23.5 & 19.9 & 21.7 \\
\hline $\mathbf{T}_{7}$ & 95.0 & 97.7 & 96.3 & 153.0 & 160.1 & 156.5 & 182.7 & 195.1 & 188.9 & 26.2 & 23.0 & 24.6 \\
\hline $\mathbf{T}_{8}$ & 77.0 & 91.3 & 84.2 & 136.7 & 144.9 & 140.8 & 167.3 & 179.5 & 173.4 & 24.4 & 20.5 & 22.5 \\
\hline $\mathbf{T}_{9}$ & 87.0 & 90.0 & 88.5 & 138.3 & 140.2 & 139.3 & 172.0 & 184.2 & 178.1 & 24.7 & 20.7 & 22.7 \\
\hline $\mathbf{T}_{10}$ & 92.0 & 98.0 & 95.0 & 164.7 & 156.2 & 160.4 & 184.0 & 196.0 & 190.0 & 25.3 & 22.5 & 23.9 \\
\hline $\mathbf{T}_{11}$ & 104.0 & 118.3 & 111.2 & 182.3 & 186.5 & 184.4 & 208.3 & 220.2 & 214.3 & 26.9 & 23.5 & 25.2 \\
\hline $\mathbf{T}_{12}$ & 93.7 & 98.7 & 96.2 & 154.0 & 161.4 & 157.7 & 185.0 & 197.3 & 191.1 & 26.0 & 23.7 & 24.9 \\
\hline SEm \pm & 3.5 & 1.7 & 1.2 & 7.8 & 6.5 & 6.6 & 6.9 & 5.4 & 5.7 & 1.6 & 0.8 & 1.2 \\
\hline$C D(p=0.05)$ & 10.2 & 4.85 & 5.85 & 22.8 & 18.8 & 19.4 & 20.3 & 15.8 & 16.6 & 4.7 & 2.3 & 3.5 \\
\hline
\end{tabular}


Table. 3 Correlation matrix of crop growth performances by maize under different INM modules

\begin{tabular}{|l|l|l|l|l|}
\hline \multirow{2}{*}{ Parameters } & \multicolumn{3}{|c|}{ Maize plant height } & \multicolumn{1}{l}{$\begin{array}{l}\text { Seed } \\
\text { index }\end{array}$} \\
\cline { 2 - 5 } & 45 DAS & 60 DAS & $\begin{array}{l}\text { 90 } \\
\text { DAS }\end{array}$ & \\
\hline 45 DAS & 1.000 & & & \\
\hline 60 DAS & $0.921^{* *}$ & 1.000 & & \\
\hline 90 DAS & $0.993 * *$ & $0.944 * *$ & 1.000 & \\
\hline Seed Index & 0.553 & 0.370 & 0.547 & 1.000 \\
\hline
\end{tabular}

* Significant at $5 \%$; ** Significant at $1 \%$

Fig.1 Plant height by maize under various INM Modules

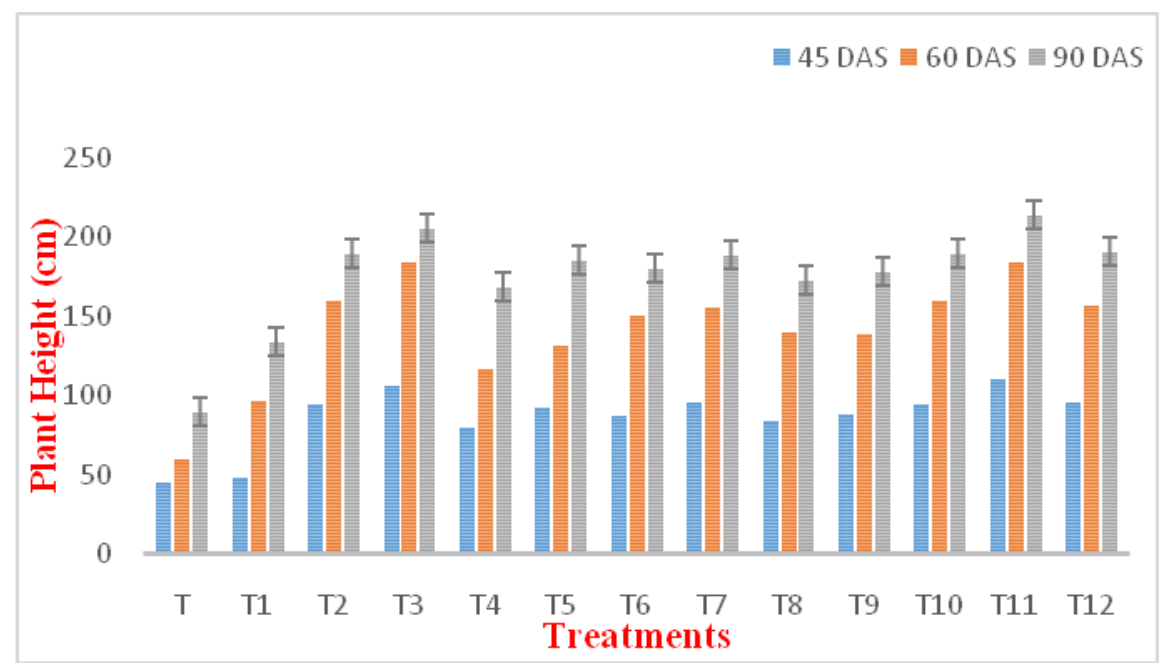

Fig.2 Seed Index by maize under different nutrient management practices

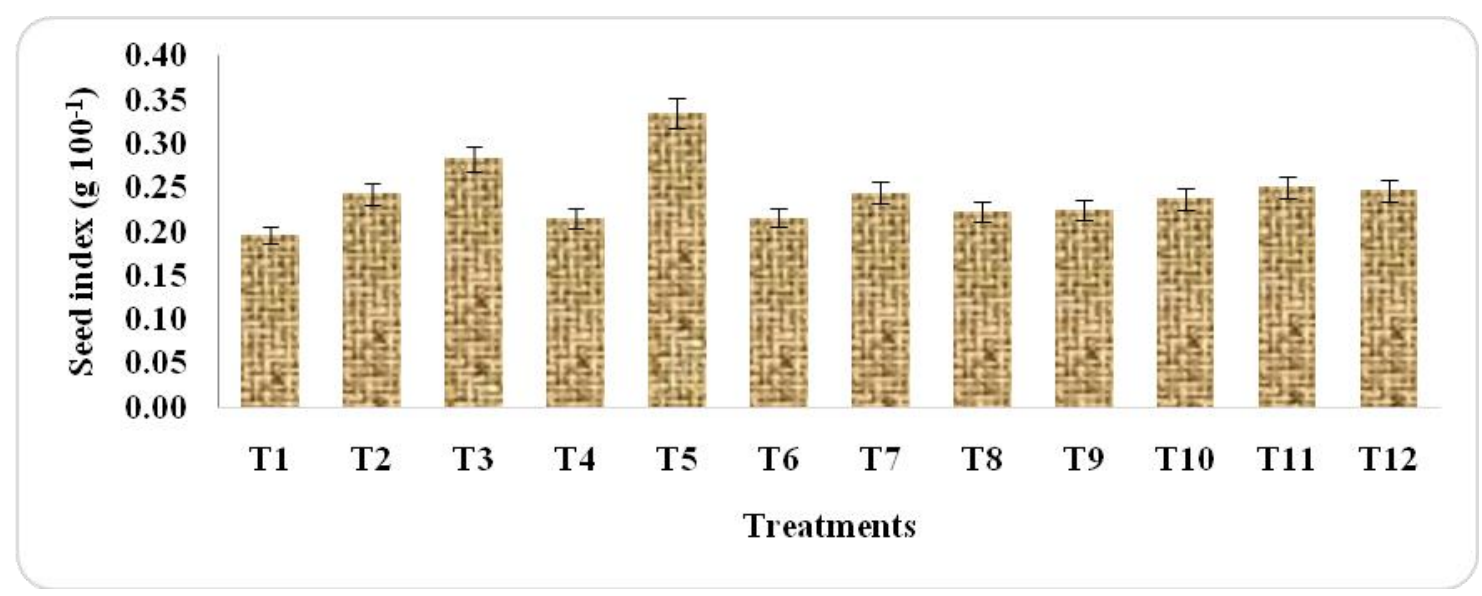

The seed index of maize and chickpea found significantly influenced under the integrated nutrient application (Table 2; Fig. 1 and 2). The pooled data of two years were indicated highest seed index under the treatment $\left(\mathrm{T}_{5}\right)$ receiving 75\% STCR dose + FYM @ $5 \mathrm{t} \mathrm{ha}^{-1}$ followed by the treatment with STCR recommended dose of fertilizers. Addition of 
organic manure improves soil physicochemical properties by mediating rhizospheric effect and nutrient dynamics that help improve crop performance (Pingoliya et al., 2014; Mohbe et al., 2015 \& 2018; Selim, 2020; Dotaniya, et al., 2020). Incorporation of organic sources during the crop production; it mediated the soil- plant nutrient dynamics by mineralization kinetics. It secreted different type of organic acids during the microbial decomposition and enhanced soil aggregates and most of the crops yield potential (Dotaniya et al., 2016). Decomposition of organic matter act as source of energy to soil biota and enhance microbial population and diversity. Gathala et al., (2013) reported that incorporation of maize residue every year enhanced wheat crop yield by 0.5 to 1.2 tonnes $\mathrm{ha}^{-1}$ over farmer's practices. The above finding was supported by (Dotaniya et al., 2013; Aher et al., 2015; Meena et al., 2015; Dharwe et al., 2019; Salame et al., 2020).

\section{Correlations}

The correlation between crop performance viz., 45, 60, and 90 DAS with crop seed index of maize are presented in Table 3. Plant height of maize was found highly significant and positively correlated with maize seed index. The correlations between plant height of maize at 60 and 90 DAS was significant and positively correlated with seed index $(r=0.921,0.993 \& 0.944)$. The higher height of plants might be produce bold size of seed due to more photosynthetic activities and utilization of higher sink source of the plants. These results are agreement with Gautam et al., (2018).

In conclusion, the INM modules positively influenced the performance and productivity of maize crop as compared to the sole inorganic fertilizer application. Besides the superior crop performance, the INM modules significantly enhanced and improved soil health in terms of soil physical and chemical properties. Among the various modules, (1) application of 75\% STCR dose + FYM @ $5 \mathrm{t}$ $\mathrm{ha}^{-1}$ and (2) application of FYM @ $20 \mathrm{t} \mathrm{ha}^{-1}$ to maize increased the crop growth performance and seed index in maize, improved soil physico-chemical properties and reflected as a viable technique in improving soil nutrient availability on a sustainable basis in maize cultivation.

\section{Acknowledgements}

The authors are thankful to the ViceChancellor, Swami Keshwanand Rajasthan Agricultural University, Bikaner; and Director, ICAR-Indian Institute of Soil Science, Bhopal for providing the research facility and for extending every kind of support during the course of study.

\section{References}

Agricultural Statistics (2018). Agricultural Statistics at a Glance. In: Government of India ministry of agriculture \& farmer's welfare department of agriculture, cooperation \& farmers welfare directorate of economics and statistics, published by GOI.

Aher, S.B., Lakaria, B.L., Swami, K., Singh, A.B., Ramana, S., Ramesh, K. and Thakur, J. K. (2015). Effect of organic farming practices on soil and performance of soybean (Glycine max) under semi-arid tropical conditions in Central India. Journal of Applied and Natural Science, 7(1): 67-71.

Dharwe, D.S., Dixit, H.C. Dotaniya CK, Doutaniya RK, Mohbe S. and Tarwariya, M.K. (2019). Effect of phosphorus and sulphur on yield attributes, nutrient content and Nutrient uptake of green gram in Bundelkhand soil. Int. Journal of Current Research, 
11(11): 8225-8229.

Dotaniya, C.K., Yashona, D.S., Aher, S.B., Rajput, P.S., Doutaniya, R.K., Lata, M. and Mohbe, S. (2020). Crop Performance and Soil Properties under Organic Nutrient Management. International Journal of Current Microbiology and Applied Sciences,9(4): 1055-1065.

Dotaniya, C.K., Niranjan, R.K., Kumar, U., Lata, M., Regar, K.L., Doutaniya, R.K., Mohbe, S. and Jadon, P. (2019). Quality, yield and nutrient uptake of fenugreek as influenced by integrated nutrient management. International Journal of Plant \& Soil Science,29(3): 1-7.

Dotaniya, M.L., Sharma, M.M., Kumar, K., and Singh, P.P. (2013). Impact of crop residue management on nutrient balance in rice-wheat cropping system in an Aquic hapludoll. The Journal of Rural and Agricultural Research, 13: 122-123.

Dotaniya, M.L., Datta, S.C., Biswas, D.R., Dotaniya, C.K., Meena, B.L., Rajendiran, S., Regar, K.L. and Lata, M. (2016). Use of sugarcane industrial byproducts for improving sugarcane productivity and soil health-a review. International Journal of Recycling of Organic Waste in Agriculture,5(3):185194.

FAO. (2009). Maize, rice and wheat: area harvested, production quantity, yield. Statistics Division. FAO, Rome. http://faostat.fao.org (accessed $20 \mathrm{Oct}$ 2019).

Gathala, M.K., Kumar, V., Sharma, P.C., Saharawat, Y.S., Jat, H.S., Singh, M., Kumar, A., Jat, M.L., Humphreys, E., Sharma, D.K., Sharma, S.and Ladha, J.K. (2013). Optimizing intensive cereal-based cropping systems addressing current and future drivers of agricultural change in the northwestern Indo-Gangetic Plains of India.
Agriculture, Ecosystems \&

Environment, 177: 85-97.

Gautam,S., Shrestha, A. Santosh, K.C. and Amgain, L.P. (2018). Evaluation of improved nutrient management in yield and economics of hybrid maize in Jhapa, Nepal. Journal of Pharmacognosy and Phytochemistry, SP1: 1160-1163.

Gomez, K.A. and Gomez, A. (1983). Statistical procedures for agricultural research $\left(2^{\text {nd }}\right.$ edition), John Willey and sons, New York, pp. 1-68.

Hasan, M.M., Ray, T.K., Islam, K.M.M., Ali, S.M.Y., Muhammad, N., Rahman, M.D.A. and Barman, N.C. (2018). Growth and Yield of Hybrid Maize as Influenced by Fertilizer Management. Turkish Journal of Agriculture - Food Science and Technology,6(12): 17271733.

Lakaria, B.L., Singh, M., Reddy, K.S., Biswas, A. K., Jha, P., Chaudhary, R. S., Singh, A. B. and Subba Rao, A. (2012). Carbon addition and storage under integrated nutrient management in soybean-wheat cropping sequence in a Vertisol of Central India. National Academy Science Letters, 35(3):131137.

Meena, B.P., Biswas, A.K., Singh, M., Chaudhary, R.S., Singh, A.B., Das, H. and Patra, A.K. (2019). Long-term sustaining crop productivity and soil health in maize-chickpea system through integrated nutrient management practices in Vertisols of central India. Field Crops Research, 232:62-76.

Meena, B.P., Kumar, A., Lal, B., Sinha, N.K., Tiwari, P.K., Dotaniya, M.L., Jat, N.K. and Meena, V.D. (2015). Soil microbial, chemical properties and crop productivity as affected by organic manure application in popcorn (Zea mays L. var. everta). African Journal of Microbiology Research, 9(21): 1402- 
1408.

Mohbe, S., Mishra, U.S. and Pandey, R.C. (2015). A study on organic manure on green gram (Phaseolus radiata L.) under rainfed condition of Chitrakoot area, Trends in Biosciences, 8(23): 6551-6554.

Pingoliya, K.K., Mathur, A.K., Dotaniya, M. L., Jajoria, D. K. and Narolia, G. P. (2014). Effect of phosphorus and iron levels on growth and yield attributes of chickpea (Cicer arietinum L.) under Agroclimatic zone IV A of Rajasthan, India. Legume Research, 37: 537-541.

Salame, R., Mishra, U.S., Mohbe, S., Subhash, Dotaniya, C.K., Pahade, V., Doutaniya, R.K. and Wagadre, D. (2020). Influence of growth and yield attributes of sesame (Sesamum indicum L.) by sulphur and phosphorus different combination fertilizer levels under the rainfed condition. Indian Journal of Pure \& Applied Biosciences, 8(4), 115124.

Selim, M.M. (2020). Introduction to the Integrated Nutrient Management Strategies and Their Contribution to Yield and Soil Properties. International Journal of Agronomy, 20: 1-14.

Sharma, A.R. and Behera, U.K. (2009). Recycling of legume residues for nitrogen economy and higher productivity in maize (Zea mays)-wheat (Triticum aestivum) cropping system. Nutrient Cycling in Agroecosystems, 83(3):197-210.

Singh, M. and Wanjari, R.H. (2012). Potassium responses and requirement of crops grown in Vertisols: Experiences from long-term fertilizer experiment. Indian Journal of Fertilizers, 8(3): 2632 .

\section{How to cite this article:}

Dotaniya, C.K., B.L. Lakaria, Yogesh Sharma, A.K. Biswas, B.P. Meena, M.L. Reager, S.R. Yadav and Aher, S.B. 2020. Physiological parameter of Maize as Influenced by INM Modules under Maize-Chickpea Sequence in a Vertisol of Central India. Int.J.Curr.Microbiol.App.Sci. 9(09): 2745-2753. doi: https://doi.org/10.20546/ijcmas.2020.909.341 